漏斗胸に対する胸腔鏡下胸骨挙上術（Nuss 法）と 従来の胸骨挙上術の術式・合併症に関する比較検討

\author{
大阪市立大学大学院臓器器官病態外科学 (第?2外科), \\ 大阪市立総合医療センター小児外科*，腚川キリスト教病院小児外科** \\ 諸富嘉樹大野耕一中平公士* \\ 塩 川智 司**辻本 嘉 助** 木下 博 明
}

漏斗胸に对する胸腔鏡下胸骨举上術 (Nuss 法) と従来の胸骨挙上術を比較した。従来 群60例 (男: 女 $=52: 8$, 平均 6 歳) と Nuss 群26例 (24:2, 平均 8 歳 6 力月) を対象 とした。従来群の手術時間, 出血量, 手術から帰宅までの期間は299土61分, $170 \pm 206 \mathrm{~g}$,

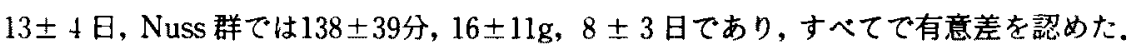
Nuss 法では十分に胸骨が挙上され，手術痗痕も小さく美容上満足できるものであった。 合併症として従来群の 5 例で血性胸水，内胸動脈損傢，皮成壊死，bar の shift がみられ た。また Nuss群の 4 例で術中の肺損傷による気胸, 断裂したwireによる肺損傷と胸腔 内異物, bar の shift, flipping がみられた. Steel bar うち 3 例て wire が断裂したことから, bar の固定法にはさらなる検討と工夫が必要であ

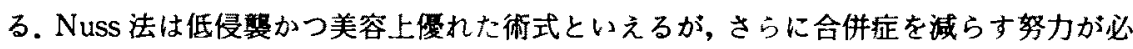
要である.

索引用語：漏斗胸, 胸骨挙上術, 胸腔鏡下手術, Nuss 法, 低侵襲漏斗胸手術

\section{緒言}

漏斗胸に対する治療の目的の一つは美容上の改善で あるが，これまでの胸骨挙上術は前胸部に手術洀痕が 残るうえに侵擎の大きい術式であった。これに対して Nuss ら゙が発表した術式は手術疫痕が小さく，低侵襲 手術として急速に広まってきだ2 の歴史は浅く，いまた十分な検討はなされていない。 そこでわれわれは胸腔鏡を用いた胸骨挙上㭪の特徵を 検討するため，従来の胸骨挙上術と比較検討した。

対象および方法

1972年 2 月から 2002 年 6 月まてに手術を行った漏斗 胸86例を対象とした，全例心肺機能に異常はなく，日 常生活に支障はなかった。われわれは，より侵熟の低 い治療法を求めて，1999年 8 月以降胸腔鏡下胸骨挙上 術(以下，Nuss 法）を採用した。1999年 7 月以前に従 来の胸骨挙上術を行った60例を従来群，それ以降に

2002 年 8 月 5 日受付 2002 年 12 月 16 日採用

《所属施設住所》

于545-8585 大阪市阿倍野区九且町 $1-4-3$
Nuss 法を行った26例を Nuss 群とした. Nuss 法を採 用するようになったのちは、患児および家族に従来法 と Nuss 法の術式, 利点, 起こり得る合併症を詳細に説 明した。そして患児および家族の意向に従って術式を 選択したところ，26例ともNuss 法を希望した。胸郭変 形の程度は胸部X線写真側面像から Vertebral Index

(以下，VI）を算出して評価した (図 1 $)^{9110)}$.

従米ひ胸骨挙上術では前胸部に横切開をおき, 胸箭 を剥離して骨性胸郭に達したのち，肋軟骨膜を残して 変形した肋軟骨をすべて切除した. 1 本の steel barを 胸骨の背側に插入し，左右の肋骨を支えとして胸骨を 挙上した（図 2)。45例では wireまたは非吸収系を用 いて bar 胸骨と肋骨に固定し，15例では吸収系を用 いて固定した．枷軟骨が再生した術 6 力月以降にbar を报去した ${ }^{11123}$ 。

Nuss 法では両側の中腋窩線と最陷凹部の高さとの 交点を中心として約 $3 \mathrm{~cm}$ の横切開を掯いた。腹側に 向けて皮下を剩離して両側銷骨中線上第 4 または第 5 助間て胸腔に入った，右側から剥離鉗子を胸照に摷入 し, 胸腔鏡下に右胸腔，前繸隔，左胸腔の順に進めた。 


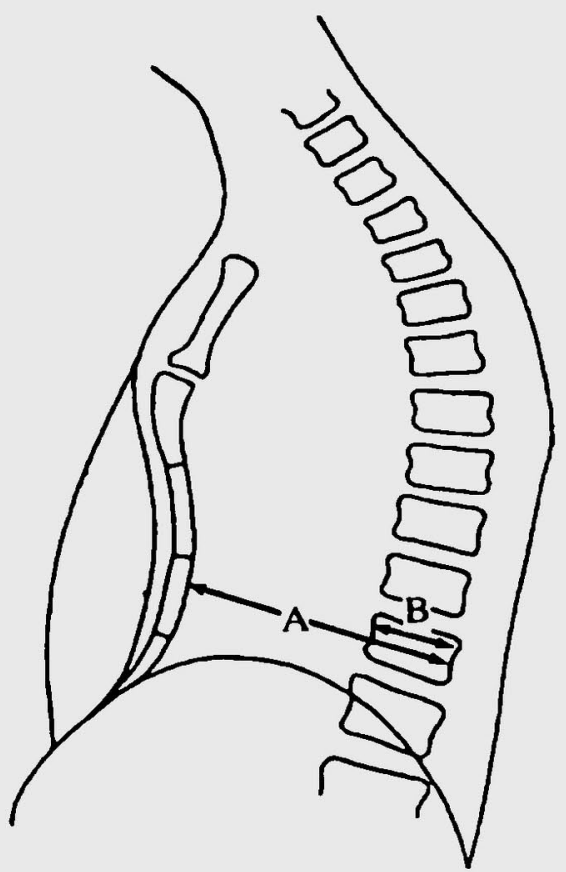

図 1 胸部単純X線写真側面像による胸郭变形 の評価法"' (Vertebral Index $(\mathrm{VI})=\mathrm{B} \div \mathrm{A} \times$ 100)

血管テープを剥離鉗子の先に把持して引き抜き, 弧状 に形成した steel bar 血管テープに結禁して,再び右 胸腔，前緹隔，左胸腔の順に誘導した，背側凸に㨂入 した bar を180度反転して胸骨を挙上した。初期の 5 例では wire を用いて bar の両端を肋骨に固定した。 他の21例では wireで bar の片端に stabilizer を固定 し，さらに吸収禾を用いてbar および stabilizerを周 囲の筋肉に縫着した（図 3 )。また初期の症例では 10 $\mathrm{mm}$ の胸腔鏡を用いたか，最近の症例では $3 \mathrm{~mm}$ の胸 腔鏡を使用していう，19歳の1例では 2 本のbar を插 入レ, 残りの25例では 1 本のbar を用いた. Nuss らい の報告に準し, 術後 2 年を経過した 5 例は bar を抜去 した5゙|3\}.

従来群と Nuss 群の 2 群間で手術時間, 出血最, 術後 から外泊または退院までの期間, 術後合併症, 両群の 術前後のVIを比較㛟討した。検定には paired $\mathrm{t}$-test, unpaired t-test, Fisher's exact probability test を用 い, $\mathrm{p}<0.05$ を有意差ありとした。

\section{成 績}

両群の背景をみると従来群の手術時月齢は， $72 \pm 46$ カ月, Nuss 群は102士61カ月であり Nuss 群で有意に

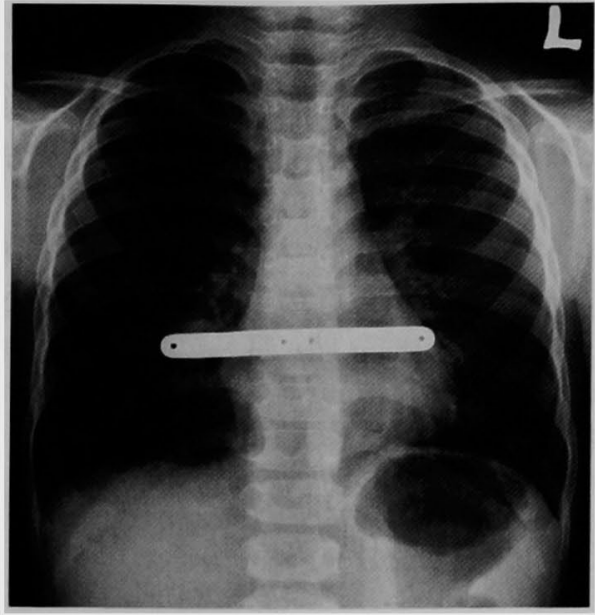

図 2 従来法の胸骨挙上術後の胸部単純X線正面 写真：変形した胁軟骨を切除し、両側の肋骨を 支えとして胸骨を挙上した。

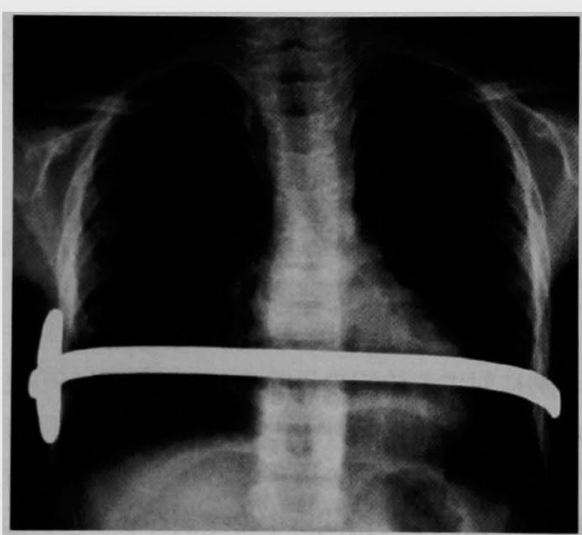

图 3 Nuss 法術後の胸部単純 $\mathrm{X}$ 線正面写真： 弧状に形成した steel barを㨉入し，180度回 転して胸骨を挙上した。

高かった。従来群の男女比はうつ：8，Nuss 群では24： 2で有意差はなかった，胸部X線写真を検討できた従 来群34例と Nuss 群26例の術前の VIは34.1 7.8 と $37.4 \pm 4.6 て ゙ あ り$ 有意差はなかった。

従来群の手術時間と出血量は $299 \pm 61$ 分, $170 \pm 206 \mathrm{~g}$

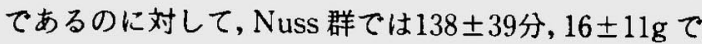
あり，有意に Nuss 群で手術時間が短く,出血量が少な かった，手術から外泊または退院までの期間は従来群 $13 \pm 4$ 日, Nuss 群 $8 \pm 3$ 日であり，有意に、Nuss 群 で短かった。

両群とも致死的な合併症はみられなかった，従来群 
表 1 従来の胸骨挙上術と Nuss 法の比較

\begin{tabular}{|c|c|c|c|c|c|c|c|}
\hline & $\begin{array}{c}\text { 患者数 } \\
\text { (人) }\end{array}$ & 月龄** & 男/女 & $\begin{array}{c}\text { 手術時間** } \\
\text { (分) }\end{array}$ & $\begin{array}{c}\text { 出血量** } \\
(\mathrm{g})\end{array}$ & $\begin{array}{c}\text { 外泊または退院*" } \\
\text { までの期間（日） }\end{array}$ & $\begin{array}{l}\text { 合併症 } \\
\text { (症例数) }\end{array}$ \\
\hline 従来法 & 60 & $72 \pm 46$ & $52 / 8$ & $299 \pm 61$ & $170 \pm 206$ & $13 \pm 4$ & 5 \\
\hline Nuss法 & 26 & $102 \pm 61$ & $24 / 2$ & $13 x \pm 39$ & $16 \pm 11$ & $8 \pm 3$ & 4 \\
\hline
\end{tabular}
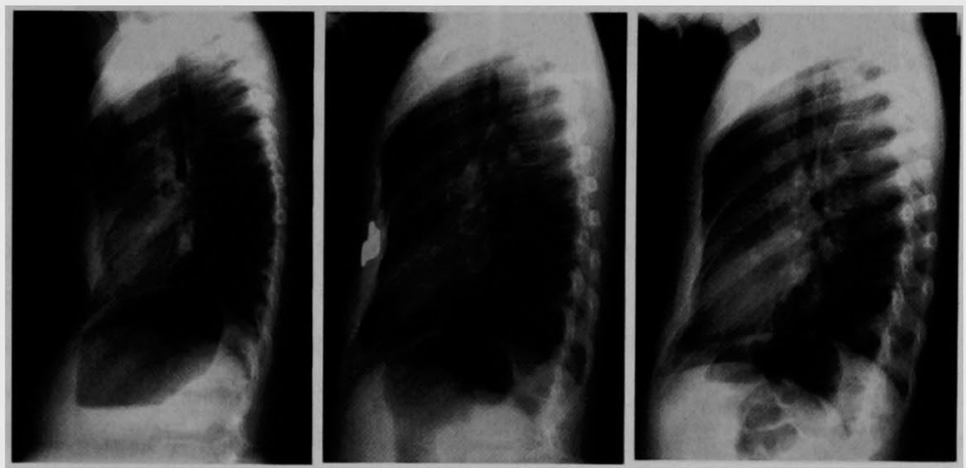

図 4 従来法の術前後の胸部単純 $\mathrm{X}$ 線側面写真：術前 (左)，胸骨挙上術後(中), bar 抜去術後 (右).
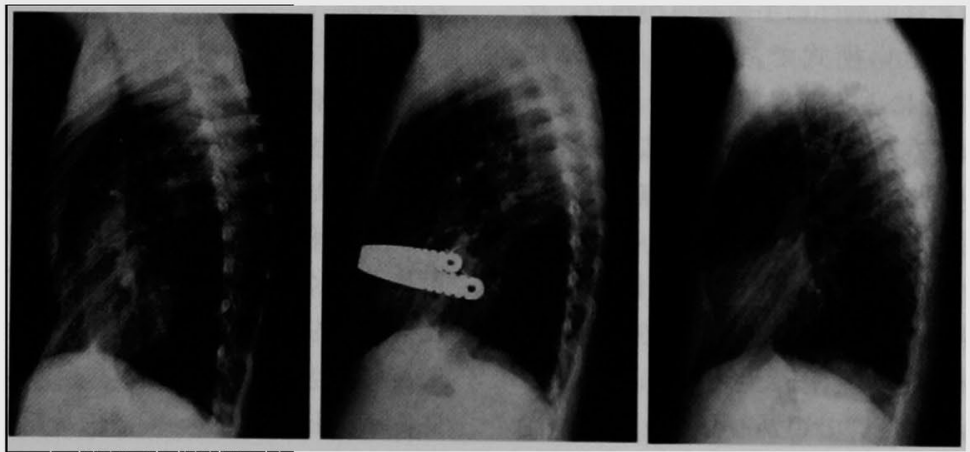

图 5 Nuss 法の術前後の胸部単純 X 線側面写真：術前 (左)，Nuss 法術後(中)， bar 抜去術後（右）.

の 5 例で血性胸水(1), 内胸動脈損偍(1)，皮膚壤死(2), bar の shift (2)がみられたが, 再手術を要した症例はな かった. また Nuss 群の 4 例で術中の肺損㑥による気 胸(1)，断裂した wireによる肺損傷と胸腔内異物(1)， bar の shift (2), bar の flipping (1)がみられた。合併症 の発生頻度は両群間で有意差はなかったか，Nuss 群 のうち wire で固定した 5 例中 3 例で wire が断裂し, 合併症の原因となっだ、このうち胸腔内異物をきた した症例では，barを抜去する際に胸腔鏡を用いて wireの断片を摘出した。また広篦囲かつ非対称な陥凹
を挙上するために 2 本の bar を挿入した19歳の症例 では， stabilizer を用いて bar を固定したにもかかわ らず頭側の bar が flipping したため, bar を抜去せざ るを得なかった(表 1 )。

術前と bar 抜去術後の胸部X線写真が検討できた

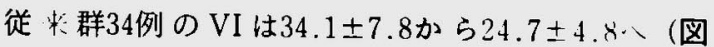

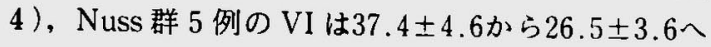
改善していた (図 5 ). 両群の術後のリに有意差は認 められなかった. Nuss 群ではbar 抜去後 1 年 3 力月 から 7 力月間, 従来群では26年 3 力月から 2 年 7 力月 

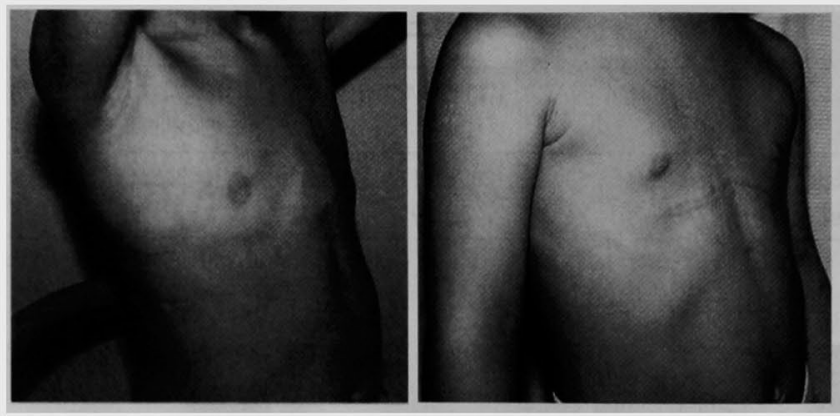

図 6 術後の胸師形態：Nuss 法 (左) は従来の術式（右）と比へて手 術鹤痕が小さく，美容的に優れている。

間経過を観察しているが，再宿凹は認めていない。

$$
\text { 考察 }
$$

漏斗胸は年齢とともに陥凹が深くなり，心肺機能に 悪影響をおよほすといわれているが，患児の多くは日 常生活に支障はない，従って治療を希望する多くの患 児とその家族の動機は美容上の問題から発生する精神 的, 社会的苦痛による ${ }^{(4)}$. 漏斗胸に対する手術の大きな 目的の一つが美容上の改善であるにもかかわらず，こ れまでの胸骨挙上術では前胸部に手術瘵痕が残り，な おかつ手術侵襲が大きい術式であった．1998年に Nuss ら”が新しい着想による低侵斐手術を紹介して 以来, 漏斗胸に対して本邦でもこの術式が広まってき た ${ }^{2335) 133}$. しかしこの術式の歴史は浅く, 利点や問題点 について十分に解明されているとはいえない.

そこで従来の胸骨挙上術を歴史的対照群として Nuss 法の特幑を検討したところ，Nuss 群で手術時間 が短く，出血量が少なかった。また手術から外泊また は退院までの期間も Nuss 群で短かったことから，従 来の胸骨举上術よりも Nuss 法の方が術後の回復が早 いと考えられ，Nuss 法は確かに minimally invasive surgery といえる.また，Nuss 法ではbar 拔去後の症 例が少なく術後の観察期間も短いため長期予後を論じ ることはできないが, bar 抜去後の VI から Nuss 法は 従来の胸骨挙上術と同程度に胸骨を挙上することがて きると思われた。ささらに Nuss 法では手術疫痕が小さ いことが大きな利点であり，美容的にも十分満足でき るものであった（図6)。 。た Nuss 法の術 2 年後に bar を抜去した 5 例に関しては，抜去術後の観察期間 は最長 1 年 3 カ月の現在, 再陥凹はみられていない.

自験例では Nuss 群の手術時年龄が従来群に比べて 高かったが，これは Nuss 群で手術適応年龄を高くし たためではない.1999年 8 月以降偶然年長児の症例が
多かったためであり，思春期以降の 5 例のうち 3 例を 初期の 8 力月の間に経験した。これらの症例でも手術 時間, 出血量は学童期以前の症例と変わらなかった。 しかし二次性徴が始まり骨性胸郭が成人に近づく思春 期以降の症例では，胁軟骨が硬く陥凹の面積が広いた め，肋骨弓に陥山が残る症例がみられた。 また思春期 以降の症例では術後の疼痛が強く離床が遅くなる傾向 があったが, 症例数が少ないため統計学的検討は行わ なかった。

Molik ${ }^{15)}$ と Fonkalsrud ら ${ }^{16)}$ は Nuss 法と従来の 胸骨挙上術を比較し, Nuss 法は手術時間が短く, 手術 疫痕が小さいが, 疼痛が長く持続し術後合併症が多く， 約10〜30\%に再手術が必要であったと述へている。こ れまでの報告では Nuss 法の合併症として bar の移動 が最も多く，約 $9 \%$ bar の shift や flipping のため に再手術を必要としていだ(17). Bar の固定には stabilizer が推奖されているが，自験例でも経験したよう に, stabilizer を用いても約 $6 \%$ に bar の移動が報告 されている゙.

また胸腔鏡を用いなかった 2 例で心損傷が報告され ており ${ }^{118)}$ ，さらに心妻炎，膿胸，胸郭出口症候群など 重篤な合併症も報告されている18).これらの合併症を 防くためには胸腔鏡は必須であり，丁寧な手術操作， 清潔操作の徹底と術直前からの抗菌郕投与が重要であ る.また bar の移動を防ぐ対策が今後の課題である ${ }^{19}$. 合併症の多くは Nuss 法を導入した初期に発生してい ることから，Nuss法にも learning curve が指摘され ており ${ }^{16) 17),}$ 症例を重ねて手技に熟練することが重要 である.

\section{結 語}

漏斗胸治療の目的は美容上の改善とそれに伴う精神 的，社会的苦痛の縟和にある．従って漏斗胸に対する 
手術は覀性疾患などに対する治療と比べて，低侵䤃で 手術㗪痕が小さく，なおかつ限りなく合併症の少ない 街式であることが要求される. Nuss 法は従来の術式 に比へて確かに低侵警かつ美容上優れた術式といえる がささらに合併症を減らす努力が必要であり, bar 抜去 後の長期的予後に関しては今後も検討すへき余地が残 る.

\section{文 献}

1) Nuss D.Kelly RE Jr, Croitoru DP, et al : A 10year review of a minimally invasive technique for the correction of pectus excavatum. J Pediatr Surg 33:545-552, 1998

2）植村貞繁，中川賀清：膤斗胸の治療．小児外科 $34: 659-664,2002$

3）植村貞繁，吉田篤史，丁田泰宏：调斗胸に対する Nuss procedure $の$ 手術経験. 日小児外会誌 37 : $264-269,2001$

4) Croitoru DP. Kelly RE Jr, Goretsky MJ. et al : Experience and modification update for the minimally invasive Nuss technique for pectus excavatum repair in 303 patients. J Pediatr Surg $37: 43 i-445,2002$

5) 大野耕一, 塩川智司, 竹内 敏他：漏斗胸に対す 万胸腔鏡下胸骨挙上術.小児外科 $33: 261-266$, 2001

6）大野耕一，塩川智司，中平公士他：漏斗胸に対す る胸腔鏡補助下胸骨举上街.小児外科 $33: 847-$ 852,2001

7) Engum S, Rescorla F, West $K$, et al: Is the grass greener? Early results of the Nuss proce. dure. J Pediatr Surg $35: 246-251,2000$

x) Hebra A: Minimally Invasive pectus surgery. Chest Surg Clin of North Am $10: 329-339,2000$

9) Backer OG, Brunner S, Larsen V: Radiologic evaluation of funnel chest. Acta Radiol $55: 249$ $-256,1960$
10）大野耕一，塩川智司，中岡垟雄地：漏斗胸の計測 による重症度判定法と手衡適応の検討。日小先放 線会誌 $15: 79-84,1999$

11）大野耕一，木下博明，塩川智司他：胸部 X線写真 による濑斗胸の重症度判定.日臨外会誌 $60: 609$ $-613,1999$

12) Ohno $K$, Nakahira M, Takeuchi $S$, et al : Indications for surgical treatment of funnel chest by chest radiograph. Pediatr Surg Int $17: 591-$ 595,2001

13）大野耕一, 井上清俊, 西田 達他：漏斗胸に対市 る胸腔鏡を用いた minimally invasive sternal elevation. 日外科系連会誌 $26: 80-85,2001$

14）大野耕一, 中岡達雄, 木下博明他: アンケート調 直に基つく漏斗胸の手術適応の検討。日小児外会 誌 $35: 832 \cdots 8,1999$

15) Molik KA, Engum SA. Rescorla FJ, et al: Pectus excavatum repair: Experience with standard and minimal invasive techniques. J Pediatr Surg 36:324-328, 2001

16) Fonkalsrud EW, Beanes S, Habra A, et al: Comparison of minimally invasive and modified Ravitch pectus excavatum repair. J Pediatr Surg $37: 413-417,2002$

17) Hebra A, Swoveland B. Egbert $M$, et al : Outcome analysis of minimally invasive repair of pectus excavatum: Review of 251 cases. J Pediatr Surg 35:25:-258, 2000

18) Moss RL, Albanese CT, Reynolds $M$ : Major complications after minimally invasive repair uf pectus excavatum: Case reports. J Pediatr Surg 36:155-158, 2001

19) Hebra A. Gauderer MWL, Tagge EP, et al : A simple technique for preventing bar displacement with the vuss repair of pectus ex. cavatum. J Pediatr Surg $36: 1266-1268,3001$ 


\title{
COMPARISON OF THORACOSCOPIC STERNAL ELEVATION (NUSS' PROCEDURE) AND CONVENTIONAL STERNAL ELEVATION FOR FUNNEL CHEST
}

\author{
Yoshiki MOROTOMI, Koichi OHNO, Masashi NAKAHIRA*, \\ Chizuka SHIOKAWA**, Kasuke TSUJIMOTO** and Hiroaki KINOSHITA \\ Second Department of Surgery, Osaka City University Medical School \\ -Department of Pediatric Surgery, Osaka City General Hospital \\ - Department of Pediatric Surgery, Yodogawa Christian Hospital
}

We compared the thoracoscopic sternal elevation for funnel chest (Nuss' procedure) with conventional sternal elevation. Subjects were 60 patients with funnel chest -52 boys and 8 girls averaging 6 years of age-undergoing conventional sternal elevation (CSE) before July 1999 and 26 patients-24 boys and 2 girls averaging 8 years and 6 months of age-undergoing Nuss' procedure after August 1999. The operating time and blood loss in Nuss' procedure ( $138 \pm 39 \mathrm{~min}$ and $16 \pm 11 \mathrm{~g}$ ) were significantly less than those of CSE (299 \pm til $\mathrm{min}$ and $170 \pm 206 \mathrm{~g}$ ). Days before returning home after Nuss' procedure ( $8 \pm 3$ days) were significantly shorter than after CSE (13 \pm 4 days). The cosmetic results of Nuss' procedure were more satisfactory than those of CSE, since, in addition to sufficient elevation of the concavity, operative scars were smaller. We noted hemothorax, injury of the intrathoracic artery, skin necrosis and shift of a steel bar in 5 of the CSE patients. Lung injury during surgery, lung injury and a foreign body in the thoracic cavity due to a broken wire, shift, or flipping of a bar occurred in 4 of the Nuss' procedure patients. We recommended use of a stabilizer for fixation of the bar, since in 3 of 5 patients whose bars were fixed with wires, wires broke and caused complications. The rate of complications did not, however, differ significantly between the 2 procedures. 'Though Nuss' procedure was recognized to be minimally invasive, more experience and work is required to dicrease complications. 